DOI: $10.17805 /$ trudy.2019.2.5

\title{
ПРОБЛЕМЫ ВЗАИМОДЕЙСТВИЯ МНОГОФУНКЦИОНАЛЬНЫХ ЦЕНТРОВ ПРЕДОСТАВЛЕНИЯ ГОСУДАРСТВЕННЫХ И МУНИЦИПАЛЬНЫХ УСЛУГ И ПЕНСИОННОГО ФОНДА РОССИЙСКОЙ ФЕДЕРАЦИИ
}

\author{
А. А. Погосов \\ Московский гуманитарный университет
}

\begin{abstract}
Аннотация: В статье называются проблемы взаимодействия Пенсионного фонда РФ и многофункциональных центров. Отмечается, что возникающие при этом взаимодействии проблемы негативно отражаются на качестве предоставляемых государственных услуг
\end{abstract}

Ключевые слова: государственные услуги; многофункциональный центр; пенсионный фонд

\section{PROBLEMS OF INTERACTION BETWEEN THE MULTIFUNCTIONAL CENTERS FOR PROVISION OF STATE AND MUNICIPAL SERVICES AND THE PENSION FUND OF THE RUSSIAN FEDERATION}

\author{
A. A. Pogosov \\ Moscow University for the Humanities
}

Abstract: The article deals with the problems of interaction between the Pension Fund of the Russian Federation and multifunctional centers. It is noted that the emerging problems have a negative impact on the quality of the provided public services.

Keywords: government services; multifunctional center, pension fund

Многофункциональные центры, оказывающие государственные и муниципальные услуги (МФЦ), начали открываться в России с 2010 г. Последние два года данный процесс пошел особенно активно. На сегодняшний день сеть офисов МФЦ охватывает не только крупные города, но и небольшие населенные пункты. Согласно официальной информации, около 94\% жителей нашей страны имеют возможность обратиться в государственные органы через службу «Одного окна».

МФЦ - это учреждение, которое является связующим звеном между органами государственной или муниципальной власти и гражданами на- 
шей страны. Одной из главных целей при создании МФЦ было упростить гражданам доступ к получению государственных и муниципальных услуг.

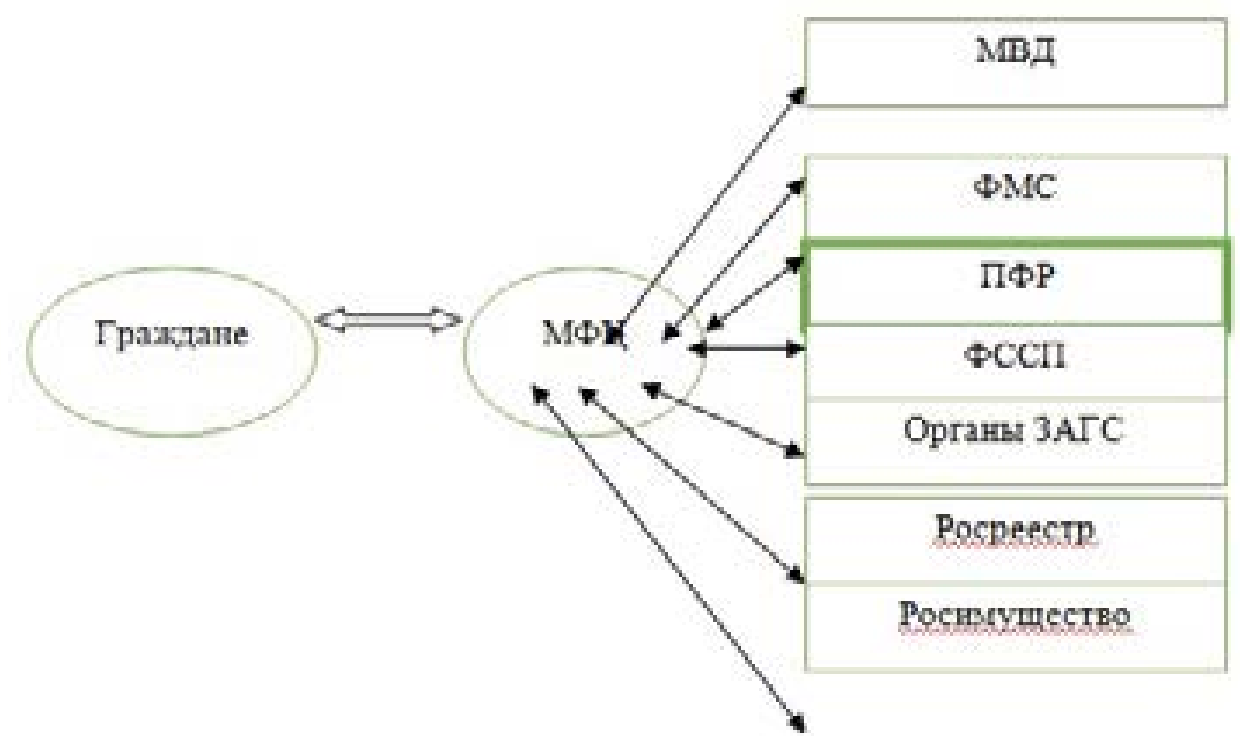

Рис. 1. Схема взаимодействия МФЦ с различными органами и службами.

Постановлением Правительства Российской Федерации № 797 от 27 сентября 2011 г. был установлен перечень услуг, которые могут быть организованы в многофункциональных центрах. В функции МФЦ входит организация получения услуг, осуществляемых органами и службами, указанными на рисунке 1.

Деятельность МФЦ регулируется Федеральным законом № 210-ФЗ от 27 июля 2010 г. Данный закон устанавливает принципы организации службы, права и обязанности самих центров, а также государственных органов при взаимодействии с МФЦ. Государственные услуги оказываются на основе соглашений о взаимодействии органов друг с другом и со службой «Одного окна». В соответствии с этим законом на муниципальные и государственные органы накладывается обязанность предоставлять МФЦ необходимые сведения, а также доступы к информационным системам, в которых такие сведения содержатся.

Несмотря на то, что МФЦ осуществляет свою деятельность уже довольно продолжительный период времени, сегодня существует огромное количество проблем, которые возникают при взаимодействии с разными государственными органами, например, с Пенсионным фондом РФ.

Государственные услуги Пенсионного фонда - одни из наиболее востребованных у населения нашей страны. В МФЦ граждане могут получить довольно обширный перечень услуг ПФР. Сотрудничество МФЦ и ПФР ре- 
гламентируется соглашением о взаимодействии между двумя органами.

Однако, несмотря на данное соглашение о взаимодействии существует ряд проблем, которые непосредственно влияют на качество и сроки предоставления государственных услуг, а именно:

1) высокая текучесть кадров специалистов МФЦ;

2) недостаточное количество времени, отведенное на обучение и повышение квалификации специалистов МФЦ;

3) отсутствие электронного документооборота между МФЦ и ПФР;

4) отсутствие доступа у сотрудников МФЦ к информационным системам ПФР.

Рассмотрим первые две проблемы. Они связаны с низким уровнем знаний у специалистов МФЦ в области пенсионного законодательства. Специалисты МФЦ владеют только поверхностными знаниями. Это ведет к тому, что при возникновении какой-то неординарной ситуации при подаче документов заявителем, специалист МФЦ не в состоянии принять правильное решение, что в свою очередь сказывается на качестве предоставляемой государственной услуги. Для того, чтобы исключить этот фактор, сотрудники ПФР в соответствии с соглашением о взаимодействии производят обучение специалистов МФЦ. Однако как показывает практика, то количество времени (обучение проводится один раз в квартал), которое затрачивается на обучение специалистов МФЦ не достаточно для того, чтобы специалисты МФЦ действительно были универсальными специалистами и полностью владели всеми знаниями и нюансами пенсионного обеспечения граждан.

Помимо недостаточного обучения специалистов МФЦ существует и другая проблема, а именно - довольно высокая текучесть кадров в МФЦ. В связи с этим образуются разрывы в квалификации. Вновь пришедших сотрудников приходится опять обучать, что также сказывается на качестве предоставления государственных услуг.

Третья и четвертая проблемы, которые существуют при взаимодействии МФЦ и ПФР, носят технический характер. У специалистов МФЦ отсутствует доступ к информационным системам и базам ПФР. В связи с этим специалисты МФЦ, при обращении к ним граждан за той или иной государственной услугой либо не могут ее оказать в режиме «онлайн» (например выдача справки), либо вовсе не могут правильно и качественно оказать государственную услугу, так как не имеют доступа к необходимым сведениям. Между МФЦ и ПФР отсутствует электронный документооборот. Передача документов из МФЦ в ПФР осуществляется на бумажных носителях, что влияет уже на сроки предоставления государственных услуг.

В связи с этим стоит сказать, что после решения проблем технического характера, а также после изменения системы прохождения обучения специ- 
алистами МФЦ, организация предоставления государственных услуг в МФЦ должна выйти на новый, более высокий уровень.

Дата поступления: 15.03.2019 г.

Погосов Артем Ашотович - студент магистратуры направления «Государственное и муниципальное управление» Московского гуманитарного университета. Адрес: 111395, Россия, г. Москва, ул. Юности, д. 5. Тел.: +7 (968) 747-10-66. Эл. адрес: arti22_mos@mail.ru

Pogosov Artyom Ashotovich, Graduate Student, programme of study "State and Municipal Administration", Moscow University for the Humanities. Postal address: 5, Yunosti St., Moscow, Russian Federation, 111395. Tel.: +7 (968) 74710-66. E-mail: arti22_mos@mail.ru

\section{Для цитирования:}

Погосов А. А. Проблемы взаимодействия многофункциональных центров предоставления государственных и муниципальных услуг и Пенсионного фонда Российской Федерации [Электронный ресурс] // Научные труды Московского гуманитарного университета. 2019. № 2. URL: http://journals.mosgu.ru/trudy/article/view/962 (дата обращения: дд.мм.гг.). DOI: 10.17805/trudy.2019.2.5 